\title{
Cz-Silicon Produced from Solar-Grade and Recycled Materials. Part II: Investigating Performances of Solar Cell Produced from Solar-Grade Cz-Silicon
}

\author{
SONG ZHANG, EIVIND JOHANNES ØVRELID, MARISA DI SABTINO, MARI JUEL, \\ and GABRIELLA TRANELL
}

This paper is the second of two, investigating the properties of P-type Cz-silicon materials and solar cells produced with recycled silicon and Elkem Solar Silicon (ESS) materials. While the focus on the first work was on the bulk properties and grown defects of the material, the current study focuses on the solar cell performances. In the processing of the solar cells, the phosphorous diffusion process was optimized to improve the bulk properties and thus to maximize the final solar cell characteristics. Results from the characterization of material defects suggest that the performances of the experimental ingots are limited by the activated grown-in defects, which should be strictly controlled during crystal growth and solar cell processing. The solar cells produced from the investigated ingots showed efficiency values up to 18.5 pct and fill factor values up to $79 \mathrm{pct}$, comparable to conventional silicon produced from poly silicon. Solar cells produced from mixed recycled and ESS material exhibit a better performance than $100 \mathrm{pct}$ recycled material. Boron and oxygen concentration levels and net doping level showed a concurrent effect on light-induced degradation (LID). Appropriate compensation was finally demonstrated to be an efficient way to improve solar cells efficiency of $\mathrm{Cz}$-silicon produced from recycled silicon, even though higher dopant concentration incurred relatively faster LID.

DOI: $10.1007 / \mathrm{s} 40553-014-0039-0$

(C) ASM International (ASM) and The Minerals, Metals, \& Materials Society (TMS) 2014

\section{INTRODUCTION}

COST- and energy-effective silicon feedstock is necessary for further progress of the photovoltaic (PV) industry. Metallurgical refining technologies may be used to produce solar-grade silicon suitable for PV applications. ${ }^{[1-3]}$ Elkem Solar Silicon (ESS) is a maturing, metallurgically produced material with a current total production energy consumption of less than $40 \mathrm{kWh} / \mathrm{kg}$ of Si ${ }^{[4]}$ compared to 120 to $180 \mathrm{kWh} / \mathrm{kg}$ of $\mathrm{Si}$ for electronic grade produced from the conventional Siemens process. ${ }^{[5-8]}$ The Elkem Solar refining process has been described in earlier publications ${ }^{[4]}$ and is still under development with process steps removed and/or simplified, promising an even cheaper and more energyefficient process in the years to come.

Another cost dilemma for the current state-of-the-art wafer production value chain - in addition to the high energy consumption - is the amount of scrap generated during ingot crystallization, cutting, sizing and wafering processes, losing more than half of the in-going silicon. Making full use of off-grade materials (top cut, off-side, crucible bed charge, etc.) is one way to improve

SONG ZHANG and MARI JUEL, Research Scientists, and GABRIELLA TRANELL, Associate Professor, are with the Department of Materials Science and Engineering, NTNU, N-7491, Trondheim, Norway. Contact e-mail: songz@material.ntnu.no EIVIND JOHANNES $\varnothing$ VRELID, Associate Professor, and MARISA DI SABTINO, Associate Professor, are with the SINTEF Materials Technology, N-7491, Trondheim, Norway.

Manuscript submitted July 1, 2014.

Article published online November 22, 2014 resources use in the PV industry and control the cost of solar cells.

Research on the effects and feasibility of using metallurgically produced silicon feedstock in both multi- and monocrystalline solar cells ${ }^{[9,10]}$ has previously been reported. The use of recycled materials in $\mathrm{Cz}$ processes has, however, received little attention. The present work aims at investigating the performance of the Cz ingots made from ESS and recycled materials, as discussed in Part I, in solar cells processed in an industrial screen printing solar cell manufacture line, optimized for the current materials.

\section{EXPERIMENTAL DETAILS}

\section{A. Sample Preparation}

As described in Part I, two experimental $\mathrm{Cz}$ ingots (Cz1 and $\mathrm{Cz} 2$ ) and a third, standard polysilicon reference ingot (RS) were grown under identical pulling conditions. No process problem or apparent structure loss was observed in the main body of all ingots. As illustrated in paper Part I, efficient yields were cut to $156 \mathrm{~mm} \times 156 \mathrm{~mm}$ quasi-square in radial direction, and then sawed to $200-\mu \mathrm{m}$-thick wafers. The properties along the ingots growth direction were characterized via analysis of twelve positions with fixed interval distance $(\sim 125 \mathrm{~mm})$ along the ingot. Four point probe (FPP) resistivity measurements were performed on wafers after rapid thermal processing to eliminate the detrimental effect of oxygen thermal donors. The ASTM F723-99 ${ }^{[11]}$ standard method was used to calculate the net doping 
levels from the measured resistivity values. Glow discharge mass spectrometry (GDMS ${ }^{[12]}$ results were used to measure the metallic impurity concentrations, the total doping concentrations (Al, B, and $\mathrm{P}$ ), and thus to calculate the net doping level.

\section{B. Solar Cell Processing}

The solar cells were manufactured using screen printing standard procedures as shown in Figure 1, including the following main steps: phosphorus emitter diffusion in horizontal furnace with $\mathrm{POCl}_{3}$ atmosphere following surface treatment by potassium hydroxide (KOH) at $\sim 355.15 \mathrm{~K}, \mathrm{SiN}_{x}: \mathrm{H}$ deposited by Plasmaenhanced chemical vapour deposition (PECVD) as the antireflection coating layer, gridded front contracts, and Al back surface field on the rear side.

In order to maximize the solar cell performance, the phosphorous diffusion process was optimized based on temperature and diffusion time. The optimized parameters of the phosphorous diffusion steps are shown in the Table I. The optimized process led to $60 \Omega / \mathrm{sq}$ sheet resistance given by FPP.

Minority carrier lifetime was characterized by quasisteady-state photo conductance to analyse the effects of solar cell processing on the recombination centres identified in Part I of this work, in particular the phosphorous diffusion and antireflection coating processes. Electrical properties and light-induced degradation (LID) were measured on the solar cells to assess the solar cells performance as well as the reliability and stability through general testing instruments, including I-V tester, photoluminescence (PL), and electroluminescence (EL). At last, external quantum efficiency (EQE) measurement shows the optical property dependence on the main spectrum.

\section{RESULTS AND DISCUSSION}

\section{A. Doping Level and Resistivity}

The concentration of the doping elements (boron and phosphorus) and main metallic impurities (aluminum,

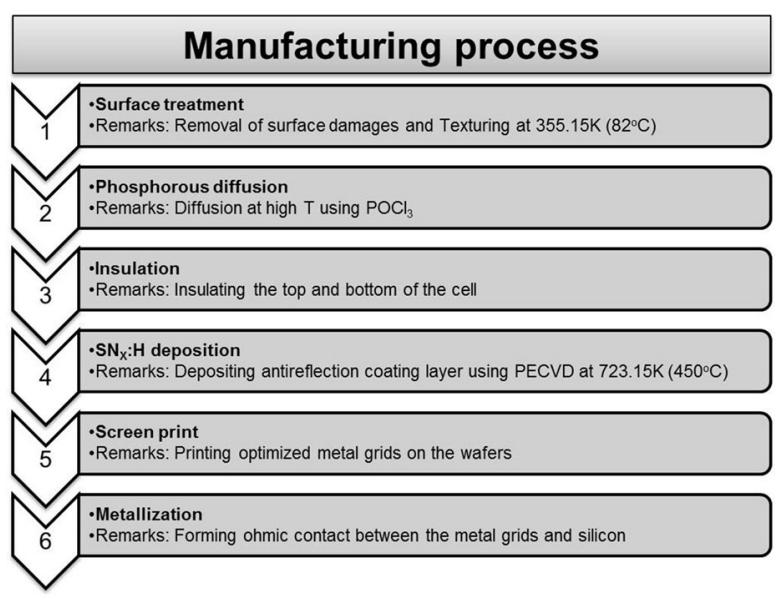

Fig. 1-The flow chart for manufacturing solar cells based on experimental wafers. iron, and copper) as measured by GDMS, and light elements (oxygen and carbon) as measured by FTIR on top and tail slabs, are shown in Table II. The main differences between the experimental and reference ingots have been discussed in Part I, i.e., both experimental ingots show slightly higher light elements concentration $\left(\mathrm{O}_{\mathrm{i}}>18 \mathrm{ppma}, \mathrm{C}_{\mathrm{s}}>2 \mathrm{ppma}\right)$ while same level of metallic impurities $\mathrm{Fe}$ and $\mathrm{Al}$ as the reference ingot were measured throughout the body of the experimental ingot. Copper levels were elevated in both the experimental ingot as compared to the reference ingot. The ESS material introduced a higher $\mathrm{P}$ level into the $\mathrm{Cz} 1$ ingot compared with the $\mathrm{Cz} 2$ ingot pulled from 100 pet top-cut silicon material. In this work, we focus on the net doping level, which affects the final solar cell parameters.

The results of the resistivity measurements after $1073.15 \mathrm{~K}$ rapid heat treatment (thermal donor killing) at different ingot heights (i.e., fraction solid) are shown in Figure 2. The resistivity throughout $\mathrm{Cz} 1$ performs consistently around $1.4 \mathrm{Ohms} \mathrm{cm}$. Uniform resistivity demonstrates that there is no majority carrier-type transition until the end of body part, i.e., transition to n-type. The relatively low and sinking resistivity of the 100 pct recycled material $\mathrm{Cz} 2$ from the seed-end to the tail is likely due to the larger amount of boron contained in the p-type top cuts. The effective dopant concentrations analysed by GDMS and resistivity are also listed in Table II as $p_{0}$ and $p_{\text {net }}$, respectively. The $p_{0}$ value was evaluated according to $[\mathrm{B}]+[\mathrm{Al}]-[\mathrm{P}]$, and the net doping level $p_{\text {net }}$ was calculated from the resistivity. ${ }^{[13]} \mathrm{It}$ is apparent that $p_{\text {net }}$ deviates from $p_{0}$ in both $\mathrm{Czl}$ and $\mathrm{Cz} 2$. The measured effective dopant concentration $([\mathrm{B}]+[\mathrm{Al}]-[\mathrm{P}])$ is small compared with the calculated net dopant level in $\mathrm{Cz} 1$, which indicates that parts of the phosphorous was combined in defects or complexes rather than totally activated in substitutional positions. Inversely, $p_{0}>p_{\text {net }}$ throughout the $\mathrm{Cz} 2$ ingot revealed the presence of a large amount of interstitial boron and B-O complexes. In this work, we will use the $P_{\text {net }}$ as the true doping level and consider the inactivated dopants as impurities. How these impurities influence the performances of solar cells produced from the two ingots is discussed based on light elements distribution and recombination properties.

\section{B. Phosphorous Diffusion}

The materials' effective minority carrier lifetime $\left(\tau_{\text {eff }}\right.$ at an injection level of $5 \times 10^{14} \mathrm{~cm}^{-3}$ ) along the ingot height is given in Figure 3 after $\mathrm{SiN}_{x}: \mathrm{H}$ passivation by a standard PECVD in a PV industrial line. The significant difference between the samples was the front junction, which was diffused in a vertical quartz tube furnace according to the different parameters shown in Table I. Similar to the results discussed in Part I, the wafers of both experimental ingots $\mathrm{Cz} 1$ and $\mathrm{Cz} 2$ show gradually increasing lifetime along the ingot growth, which was due to the decrease of light elements $\left(\mathrm{O}_{\mathrm{i}}\right.$ and $\left.\mathrm{C}_{\mathrm{s}}\right)$. Moreover, it can be seen from Figure 3 that the minority carrier lifetimes of both ingots are generally increased more than 20 pct throughout the length of the 
Table I. Optimized Phosphorous Diffusion Procedures

Double Surfaces P Diffusion Steps

\begin{tabular}{|c|c|c|c|c|c|}
\hline Steps \# & Time (s) & Temperature $\left[\mathrm{K}\left({ }^{\circ} \mathrm{C}\right)\right]$ & Carrier $\mathrm{N}_{2}(\mathrm{sccm})$ & Cleaning $\mathrm{N}_{2}(\mathrm{sccm})$ & Dry $\mathrm{O}_{2}(\mathrm{sccm})$ \\
\hline 1 & 520 & $1103.15(830)$ & 0 & 25,000 & 0 \\
\hline 2 & 180 & $1103.15(830)$ & 0 & 25,000 & 3800 \\
\hline 3 & 440 & $1113.15(840)$ & 1000 & 25,000 & 1200 \\
\hline 4 & 440 & $1131.15(858)$ & 1000 & 27,000 & 800 \\
\hline 5 & 100 & $1131.15(858)$ & 1000 & 27,000 & 800 \\
\hline 6 & 1000 & $1131.15(858)$ & 1000 & 27,000 & 800 \\
\hline 7 & 425 & $1093.15(820)$ & 0 & 25,000 & 4000 \\
\hline 8 & 470 & $1103.15(830)$ & 0 & 25,000 & 0 \\
\hline
\end{tabular}

Table II. Light Elements, Metallic Impurities and Net Doping Level for the Ingots and Samples Investigated

\begin{tabular}{|c|c|c|c|c|c|c|c|c|c|}
\hline \multirow[b]{4}{*}{ Samples \# Units } & \multirow{2}{*}{\multicolumn{2}{|c|}{ Light Elements }} & \multirow{2}{*}{\multicolumn{5}{|c|}{ Metallic Impurities Concentration }} & \multicolumn{2}{|c|}{ Net Doping Level } \\
\hline & & & & & & & & \multirow{2}{*}{\multicolumn{2}{|c|}{$\begin{array}{c}\text { GDMS } p_{0} \quad \text { Calculated } p_{\text {ne }} \\
{[\mathrm{B}]+[\mathrm{Al}]-[\mathrm{P}]}\end{array}$}} \\
\hline & \multirow{2}{*}{ Oxygen } & \multirow{2}{*}{ Carbon } & \multirow{2}{*}{$\mathrm{P}$} & \multirow{2}{*}{$\mathrm{B}$} & \multirow{2}{*}{$\begin{array}{c}\mathrm{Fe} \\
\text { (ppbw }\end{array}$} & \multirow{2}{*}{$\mathrm{Cu}$} & \multirow{2}{*}{$\mathrm{Al}$} & & \\
\hline & & & & & & & & \multicolumn{2}{|c|}{$\mathrm{E}+16\left(\right.$ atoms $\left./ \mathrm{cm}^{3}\right)$} \\
\hline Cz1 body top & 24.2 & 2 & 215 & 140 & 4 & 150 & 21 & 0.95 & 1.05 \\
\hline Czl body bottom & 17.6 & 7 & 420 & 210 & 7.2 & 220 & 30 & 0.98 & 1.06 \\
\hline $\mathrm{Cz} 2$ body top & 26.1 & 2 & - & 100 & 1.2 & 89 & 11.8 & 1.30 & 1.10 \\
\hline Cz2 body bottom & 18.9 & 8.5 & - & 170 & 20 & 220 & 21 & 2.31 & 1.68 \\
\hline $\mathrm{RS}$ body top & 20.8 & $<1$ & - & 52 & 1.1 & 60 & 18 & 0.77 & 0.44 \\
\hline RS body bottom & 12.1 & $\sim 1$ & - & 80 & 6 & 75 & 19 & 1.14 & 0.80 \\
\hline
\end{tabular}

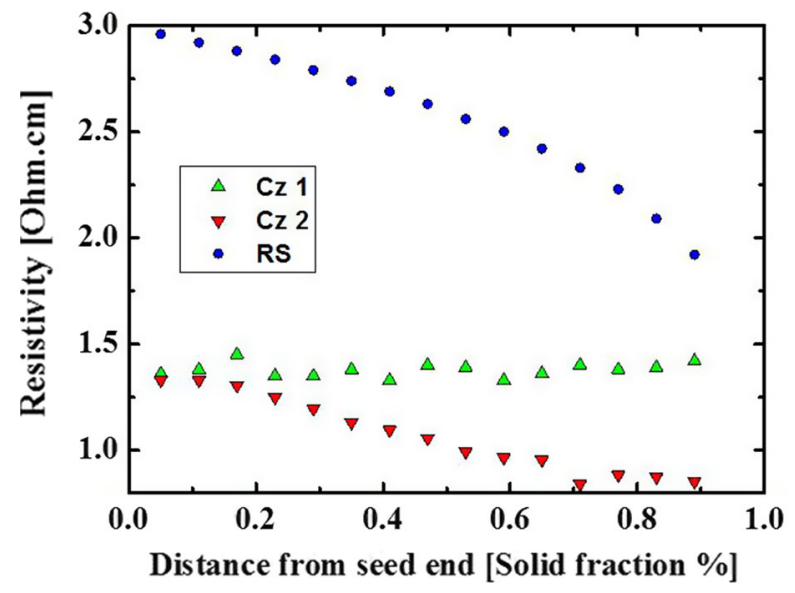

Fig. 2-Resistivity along the ingot height for all ingots.

ingots. The gettering effect of the phosphorous silicon glass still works on the experimental materials, and it also excludes the formation of detrimental oxygenrelated precipitates during phosphorous diffusion as indicated by the increased lifetime. The phosphorous gettering effect was likely influenced by the compensation in $\mathrm{Cz} 1$, as evidenced by an increasing difference in lifetime between $\mathrm{Cz} 1$ and $\mathrm{Cz} 2$ at high solid fraction. The complex mechanisms related to the increase in minority carrier lifetime during diffusion processes need more detailed investigation in future work.

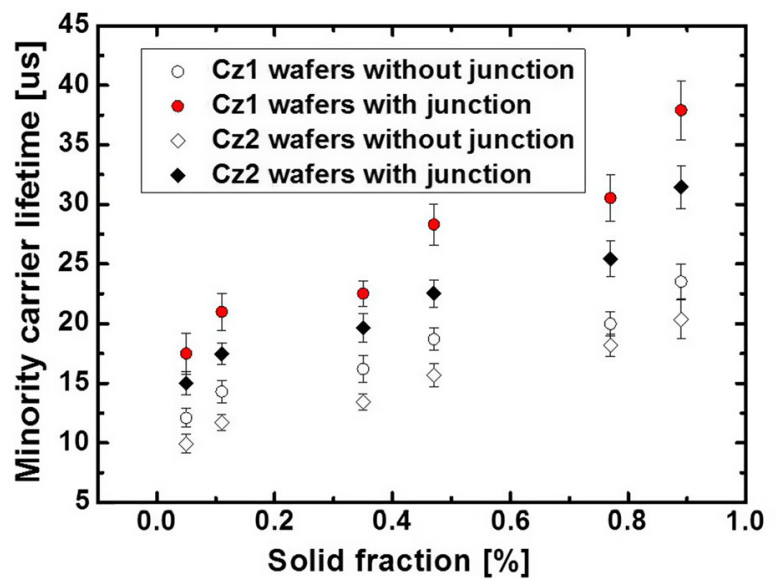

Fig. 3-Minority carrier lifetime on samples after $\mathrm{SiN}_{\mathrm{x}}: \mathrm{H}$ passivation.

\section{Solar Cell Properties}

Solar cells from wafers at twelve different positions for each investigated ingot were processed in a standard conventional line. Figure 4 reports the main characteristic parameters of these solar cells, i.e., efficiency $(E F F)$, fill factor $(F F)$, short-circuit current density $\left(J_{\mathrm{sc}}\right)$, and open-circuit voltage $\left(V_{\text {oc }}\right)$ along the ingots height. Note that all the data are from the statistical average of ten solar cells obtained from the same processing batch at $298.15 \mathrm{~K}\left(25.15^{\circ} \mathrm{C}\right)$ and one sun. The FF values of solar cells from the three ingots show relatively high values 

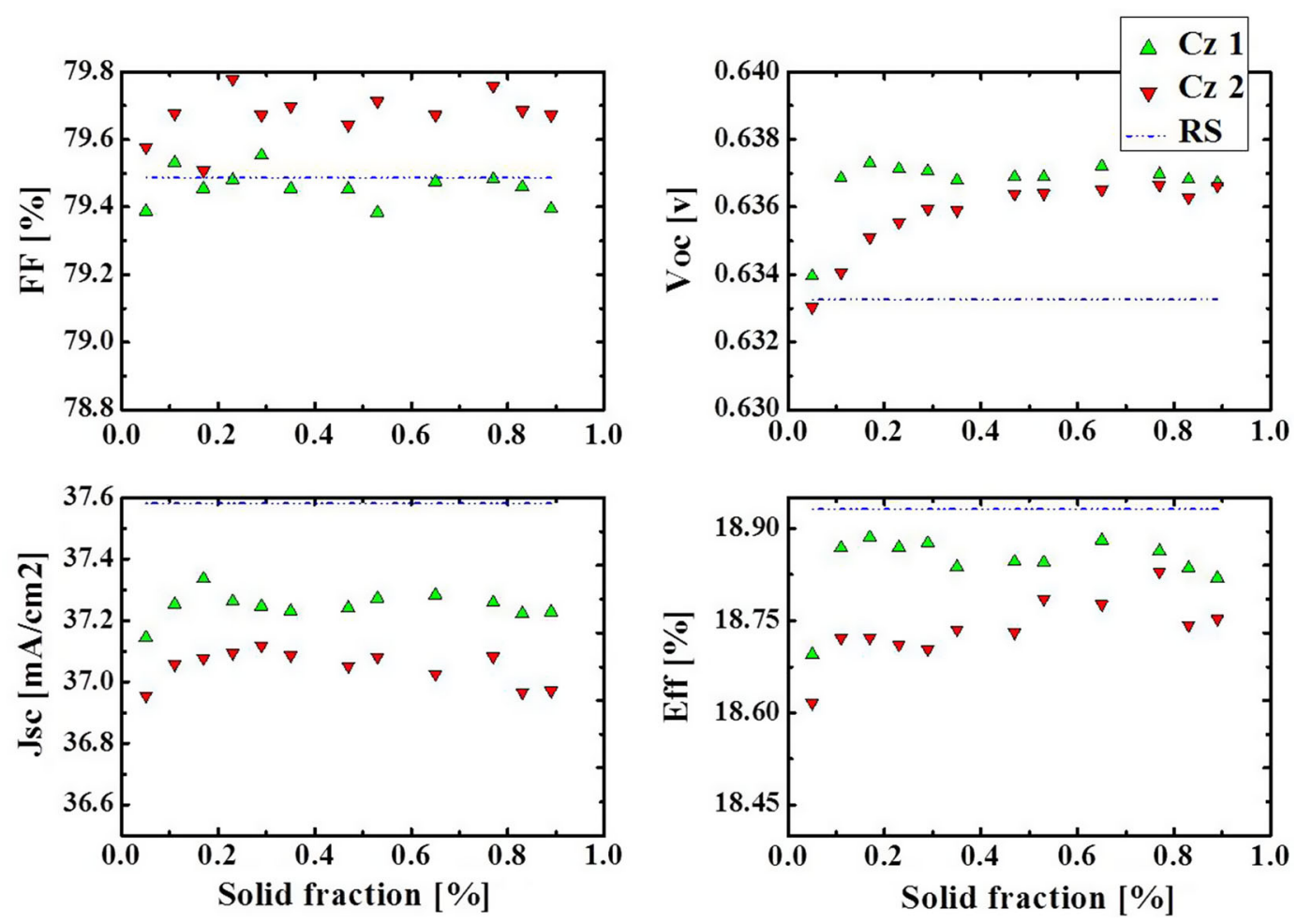

Fig. 4-Average values for solar cells performances along the height of ingots.

(>79.4 pct). Under the condition of finite sheet resistance $\left(R_{\mathrm{S}}\right)$ and shunt resistance $\left(R_{\mathrm{sh}}\right)$, FF can be expressed with the following Eq. $[1]^{[14]}$ :

$$
\mathrm{FF}=\mathrm{FF}_{0}\left(1-r_{\mathrm{s}}\right)\left[1-\frac{\left(v_{\mathrm{oc}}+o .7\right)}{v_{\mathrm{oc}}} \frac{\mathrm{FF}_{0}\left(1-r_{\mathrm{s}}\right)}{r_{\mathrm{sh}}}\right],
$$

where $\quad \mathrm{FF}_{0}=\left(v_{\mathrm{oc}}-\ln \left(v_{\mathrm{oc}}+0.72\right) /\left(v_{\mathrm{oc}}+1\right), \quad v_{o c}=\right.$ $V_{o c} /\left(\frac{n k T}{q}\right), r_{\mathrm{s}}=R_{\mathrm{s}} /\left(V_{\mathrm{oc}} / J_{\mathrm{sc}}\right), r_{\mathrm{sh}}=R_{\mathrm{sh}} /\left(V_{\mathrm{oc}} / J_{\mathrm{sc}}\right)$, and $\mathrm{n}$ is the ideality factor. It demonstrates that the FF values are not only dependent on the $v_{\mathrm{oc}}$, but also $R_{\mathrm{s}}$ and $R_{\mathrm{sh}}$. Given the I-V measurements of solar cells produced from $\mathrm{Cz} 1, \mathrm{Cz} 2$, and RS, the values of $R_{\mathrm{S}}$ and $R_{\mathrm{sh}}$ arranged in a same level, i.e., $R_{\mathrm{s}}=2 \mathrm{~m} \Omega$ and $R_{\mathrm{sh}}=700$ to $800 \Omega$. Therefore, the possible cause for slight differences between the samples is the concurrent effect of $V_{\text {oc }}$ rather than normal resistance effects. The short-circuit current densities of Cz1 and Cz2 solar cells are significantly lower than that of the reference ingot, which should be attributed to Shockley-Read-Hall recombination as demonstrated in Part I and shown in Figure 3. Higher density of as-grown defects as efficient recombination centres reduced the $J_{\text {sc }}$ significantly, compared with the reference samples. The diffusion length $\left(L=\sqrt{D_{\mathrm{e}} \tau_{\text {eff }}}\right)$ in our experimental ingots accounts for the different $J_{\mathrm{sc}}$ between $\mathrm{Cz} 1$ and $\mathrm{Cz} 2$. Compensation could introduce two concurrent effects, i.e., reducing the net doping level (positive effect) and increasing the scattering centers (negative effect). Higher $J_{\mathrm{sc}}$ in $\mathrm{Cz} 1$ than in $\mathrm{Cz} 2$ demonstrates a positive effect rather than a negative effect of the compensation in our experimental ingots.

Unlike the $J_{\mathrm{sc}}$, the $V_{\mathrm{oc}}$ in both experimental ingots shows comparable level or even higher level than the reference cells along the whole ingot. Macdonald ${ }^{[15]}$ demonstrated that the voltage for p-type base with $n^{+} p p^{+}$structure silicon may be calculated by Eq. [2]:

$$
V_{\mathrm{oc}}=\frac{K T}{q} \ln \left[\frac{\left(n_{\text {net }}+\Delta n_{\text {front }}\right)\left(p_{\text {net }}+\Delta n_{\text {back }}\right)}{n_{\mathrm{i}}^{2}}\right]+V_{\text {base }},
$$

where $n_{\text {net }}$ and $p_{\text {net }}$ are the net doping levels as shown in Table II, $\Delta n_{\text {front }}$ and $\Delta n_{\text {back }}$ are the excess carrier densities at the edges of the space charge regions of the front $n^{+} p$ junction and the rear $p p^{+}$high-low junction, respectively, $n_{\mathrm{i}}$ is the intrinsic carrier concentration, and $V_{\text {base }}$ is the electrostatic drop across the base region due to the ohmic losses and to the difference between electron and hole mobilities. Under illumination, the mean excess carrier density is directly related to the effective carrier lifetime via $\Delta n_{\text {mean }}=G \tau_{\text {eff, }}$, where $\mathrm{G}$ is the mean carrier generation rate. Therefore, three competing parameters, namely $\tau_{\text {eff, }} P_{\text {net }}$, and $V_{\text {base, }}$ determine the $V_{\text {oc }}$, for all solar cells produced in the same processes. It is clear that $P_{\text {net }}$ plays a dominant role for the difference between experimental ingots and the reference ingot. Comparing the $\mathrm{Cz} 1$ and $\mathrm{Cz} 2$ solar cells, $V_{\text {oc }}$ of $\mathrm{Cz} 1$ is generally larger than the one of $\mathrm{Cz} 2$ with higher net doping level throughout the ingot body. A reasonable explanation is that the improved minority carrier lifetime incurred by the compensation determined the $V_{\mathrm{oc}}$, even while the compensation also acted to reduce $P_{\text {net. }}$. Increased doping level and lower density of ring pattern defects in $\mathrm{Cz} 2$ gradually improved the $V_{\mathrm{oc}}$ along with the growth of the ingot. 
As such, the addition of compensated ESS feedstock to the recycled material served to improve the resulting solar cell performance. Solar cell efficiencies up to 18.72 pct $(\mathrm{Cz} 1)$ and 18.85 pct $(\mathrm{Cz} 2)$ made from the middle part of the ingot body are comparable to the 18.93 pct obtained for the reference ingot RS. However, it seems that the effect of bulk recombination at the body top is the main cause for lower efficiencies.

Figure 5 shows the EQEs of the solar cells from $\mathrm{Cz} 1$ and $\mathrm{Cz} 2$ wafers as well as the reference wafers. Note that since all the solar cells were processed in the same production line, there was no distinct difference in the reflectivity. Compared to the reference solar cell, the EQEs of solar cells based on $\mathrm{Cz} 1$ and $\mathrm{Cz} 2$ wafers show a clear reduction in EQE for the whole wavelength region, especially in the long wavelength range from 900 to

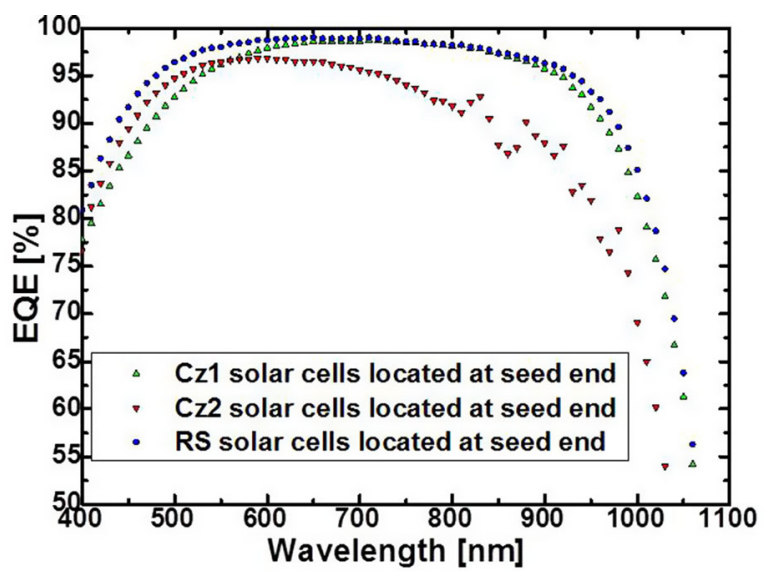

Fig. 5-External quantum efficiencies (EQEs) of the solar cells based on the Cz1, Cz2 and reference solar cells.
$1100 \mathrm{~nm}$. It is known that the long-wavelength light is mainly absorbed by the solar cells substrate due to its low absorption coefficient in crystalline silicon $(>950 \mathrm{~nm}) .{ }^{[16]}$ Thus, the lower EQEs of solar cells in the long wavelength in the $\mathrm{Cz} 1$ and $\mathrm{Cz} 2$ solar cells mainly originated from the experimental p-type silicon substrates. A slight improvement at short wavelength 400 to $650 \mathrm{~nm}$ on the $\mathrm{Cz} 2$ solar cells compared with the Cz1 solar cells can be observed. Regarding the Auger recombination mechanism, the lower quantum response at this region in $\mathrm{Cz} 1$ solar cells was probably attributed to higher emitter doping level and phosphorous-related complexes which are usually the cause for the "deadlayer" $^{6}$ on the solar cell front surface. ${ }^{[17]}$

\section{Leakage Current}

Figure 6 displays the PL images and EL images of wafers from the top of the ingots. Ring pattern areas with serious recombination, which were detected on all passivated wafers from ingots $\mathrm{Cz} 1$ and $\mathrm{Cz} 2$ as shown in Figures 6(c) and (f), discussed in Part I, disappeared after the solar cell processing illustrated in Figures 6(a) and $(\mathrm{d})$.

The leakage current for the three ingots is shown in Figure 7 and is larger in $\mathrm{Cz} 1$ and $\mathrm{Cz} 2$ than in the reference wafers. With reference to EL images of experimental seed-end wafers displayed in $b$ and e of Figure 6, white points on the images displayed leakage current points under $12 \mathrm{~V}$ inverse voltage. This is probably associated with the bulk properties, i.e., related to parts with as-grown microdefects of critical size. However, these leakage locations are not consistent with the ring defect distribution and it seems that some of these points originated from processing contamina-

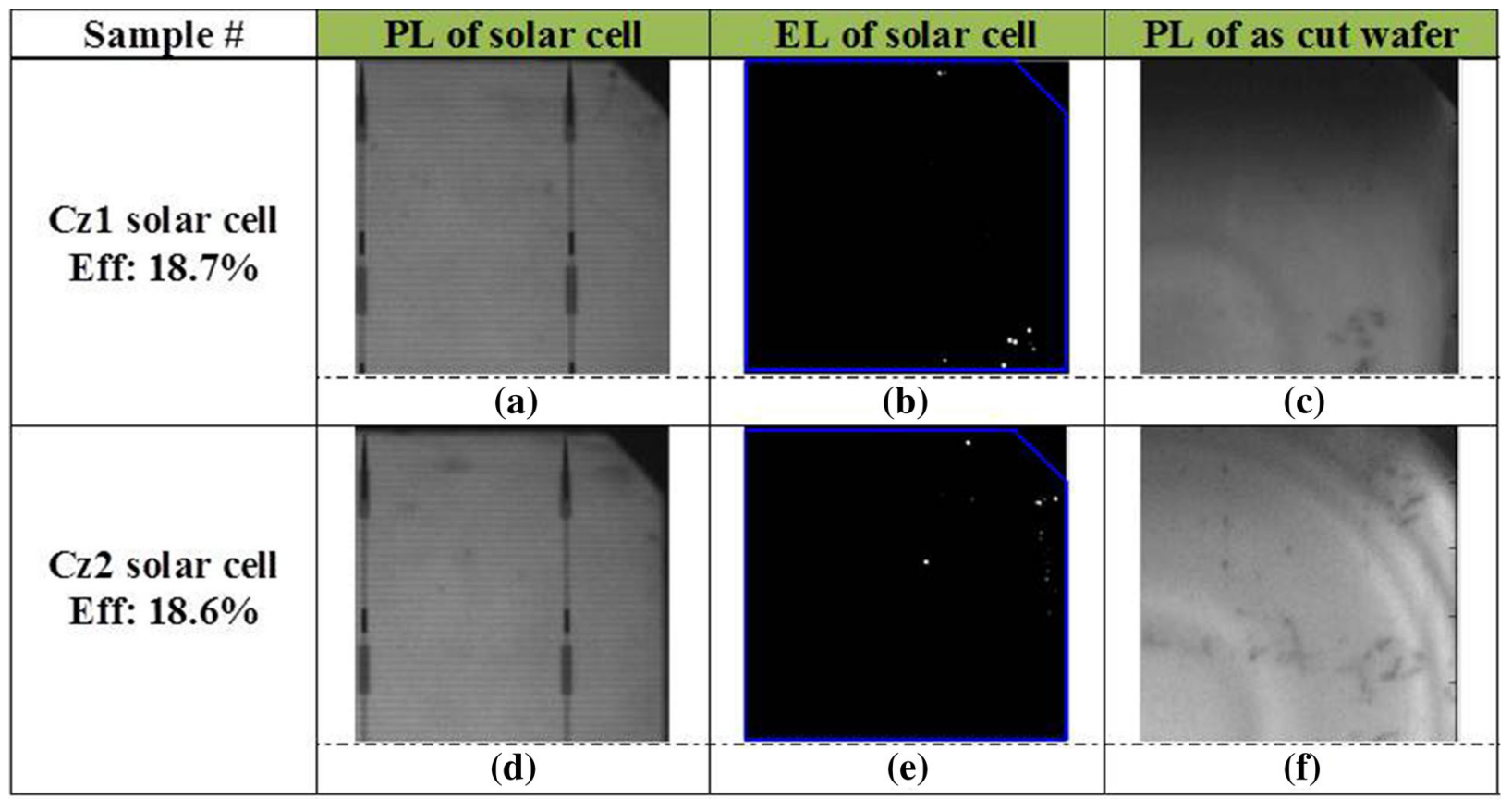

Fig. 6-PL and EL images of solar cells and passivated wafers. Where $(a),(b)$ and $(c)$ are taken from Czl seed-end; $(d)$, $(e)$ and $(f)$ are taken from Cz2 seed-end. (a) and (d) PL image of solar cell, (b) and (e) EL image of solar cell, (c) and (f) PL image of passivated wafers. 
tions (such as wire mesh belt contaminations in screen printing and firing processes) rather than ring defects. Therefore, it is proposed that ring defects did not agglomerate to a destructive structure which otherwise would give rise to a large reduction in solar cell performance. ${ }^{[18]}$ The shallow rings shown in Figure 6 illustrate that the solar cell process applied in our work had a positive effect on the solar cell performance. Phosphorus gettering and hydrogenated silicon nitride passivation $\left(\mathrm{S}_{\mathrm{i}} \mathrm{N}_{x}: \mathrm{H}\right)$ greatly improved the bulk properties by reducing the level of metallic impurities and by passivating the dangling bonds, respectively. Given the main difference between $\mathrm{Cz} 1, \mathrm{Cz} 2$, and $\mathrm{RS}$, discussed in paper I, the comparable performances of the solar cells from these ingots were mainly attributed to the elimination of ring pattern defects introduced by light elements (carbon and oxygen) during the refining $\mathrm{Cz}$ process.

\section{E. Stability and Reliability}

LID was measured on selected solar cells under 1 hour exposure to one-tenth of a sun at $298.15 \mathrm{~K}$ $\left(25.15^{\circ} \mathrm{C}\right)$, as displayed in Figure 8(a). It can be seen that the degradation in our experimental ingots was greater than that referenced along the whole ingots. $\mathrm{Cz} 1$

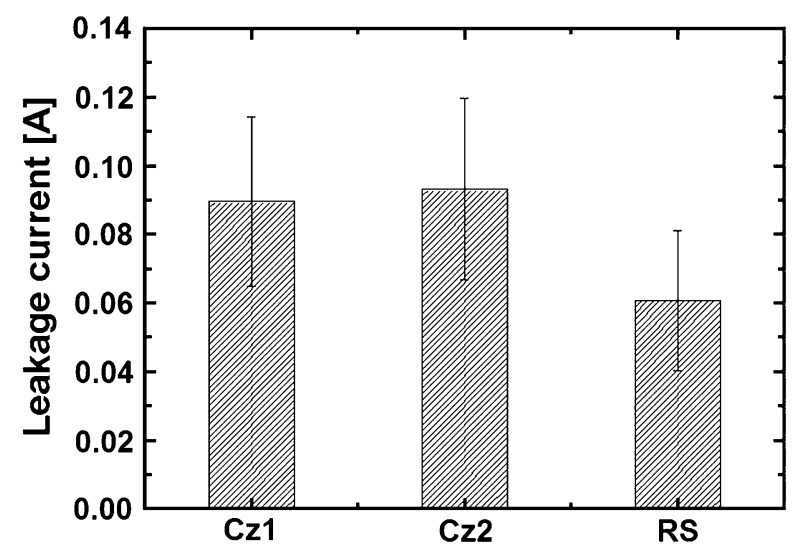

Fig. 7-Typical values of leakage current in the $\mathrm{Cz} 1$ and $\mathrm{Cz} 2$ wafers as well as reference wafers (RS). shows the most serious degradation in all samples $(\mathrm{Cz} 1$, $\mathrm{Cz} 2$, and $\mathrm{RS}$ ) throughout the whole ingot, being almost double than that of the reference solar cells at the body top of the ingot. Especially comparing the LID ratio between $\mathrm{Cz} 1$ and $\mathrm{Cz} 2$, the higher degradation rate is likely related to total boron concentration and its related complexes such as $\mathrm{B}-\mathrm{Fe},{ }^{[19]}$ given to almost same net doping level and $\left[\mathrm{O}_{\mathrm{i}}\right]$ shown in Table II. Meanwhile along with the growth of the ingots, gradually reduced $\left[\mathrm{O}_{\mathrm{i}}\right]$ mainly accounted for the lower LID ratio in both experimental ingots, while higher boron concentration in $\mathrm{Czl}$ does not worsen the degradation of the solar cells compared with $\mathrm{Cz} 2$. Besides, smaller different LID ratios between $\mathrm{Cz} 1$ and $\mathrm{Cz} 2$ at the main body part displayed in Figure 8 as well were likely thanks to relatively lower net doping level in $\mathrm{Cz} 1$ compared with $\mathrm{Cz} 2$. Therefore, slightly deviating from Macdonald's theories (namely light degradation is only determined by the net doping level), ${ }^{[20]}$ it is suggested that the LID effect is determined by the concurrent effect of boron concentration, oxygen concentration levels, and net doping levels rather than only one of these factors in our experimental ingots. Figure 8(b) shows the influence of LID on the EQE. As predicted, the degradation of the EQE was approximately 3 pct due to the increased bulk recombination at the long wavelength range $(850$ to $100 \mathrm{~nm})$. However, the results of $\mathrm{Czl}$ at short wavelength (400 to $650 \mathrm{~nm}$ ) displayed an inverse variation, increasing at least 4 pct and the phenomenon was observed on all Czl solar cells. Further experiments should be carried out to characterize the mechanism behind this phenomenon.

\section{CONCLUSIONS}

The solar cell performance of two p-type $\mathrm{Cz}$ ingots made from mixtures of ESS and recycled materials has been investigated and compared to cells made from a polysilicon reference ingot. The results may be summarised as follows:

- Solar cells made from experimental ingots pulled from recycled and ESS materials showed efficiency
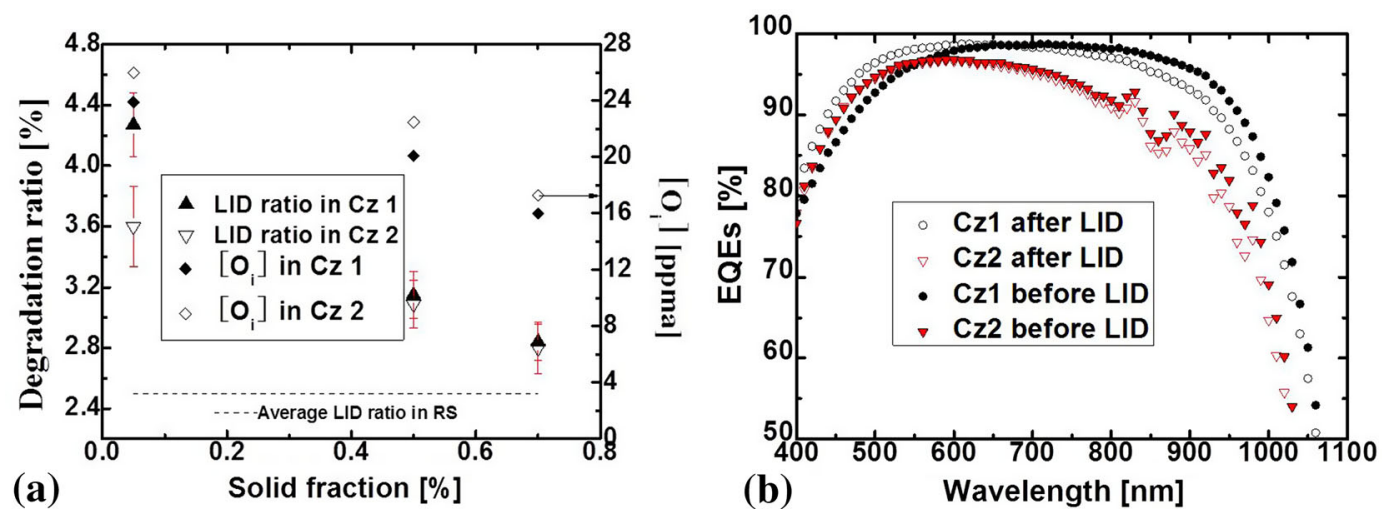

Fig. 8-Light soaking test after 1 hour of illumination under halogen lamp with an intensity equivalent to approximately one-tenth of a sun at $298.15 \mathrm{~K}\left(25.15^{\circ} \mathrm{C}\right)$ : (a) relative efficiency degradation ratio; $(b)$ external quantum efficiency before and after light induced degradation. 
values up to 18.9 pct and fill factor values up to 79 pct, compared to the reference cells.

- The compensation introduced into the recycled materials by the ESS material was shown to have a positive effect on the bulk properties and solar cell performance.

- Tailored phosphorous diffusion and $\mathrm{S}_{\mathrm{i}} \mathrm{N}_{x}: \mathrm{H}$ passivation processes could improve the bulk properties with respect to oxygen-related defects significantly, as illustrated by an increased minority carrier lifetime and annihilated ring pattern regions on PL images.

- The concurrent effect of total boron and oxygen concentration levels and net doping levels on the LID was demonstrated by light soaking measurements on $\mathrm{Cz} 1, \mathrm{Cz} 2$, and referenced samples. It was also observed that the higher doping levels of the experimental materials brought a higher rate of LID compared to the reference ingot material.

- Comparable conversion efficiencies of p-type mono crystalline solar cells from recycled and compensated materials with reference solar cells demonstrates the commercial potential of these materials in $\mathrm{Cz}$ processes with strict oxygen management.

\section{ACKNOWLEDGMENTS}

The use of materials from the RESIM ${ }^{[21]}$ project is gratefully acknowledged. We would like to thank Dr Erik Stensrud Marstein of IFE for kindly supplying the PL instruments used in this study, and Dr Chiara Modanese of NTNU for the GDMS analyses.

\section{REFERENCES}

1. T. Liu, Z.Y. Dong, Y.W. Zhao, J. Wang, T. Chen, H. Xie, J. Li, and H.J. Ni: J. Crystal Growth, 2012, vol. 351, pp. 19-22.

2. J. Safarian, G. Tranell, and M. Tangstad: Energy Proc., 2012, vol. 20, pp. 88-97.
3. E. Øvrelid, B. Geerligs, A. Wærnes, O. Raaness, I. Solheim, R. Jensen, K.Tang, S. Santeen, and B. Wiersma: Solar Grade Silicon by a Direct Metallurgical Process in Silicon for Chemical Industry, Trondheim, Norway, 2006.

4. C. Alemanya, C. Trassyb, B. Pateyronc, K. Li, and Y. Delannoy: Sol. Energy Mater. Sol. Cells, 2002, vol. 72, pp. 41-48.

5. C. Zahedi, E. Enebakk, K. Friestad, M.G. Dolmen, J. Heide, T. Buseth, R. Tronstad, and C. Dethloff: Solar Grade Silicon from Metallurgical Route. International PVSEC-14, Bangkok, 2004.

6. M. Heuer: Chapter Two-Metallurgical Grade and Metallurgically Refined Silicon for Photovoltaics, Semiconductors and Semimetals 89 (2013) 77-134.

7. V. Hoffmann, K. Petter, J. Djordjevic-Reiss, E. Enebakk, J.T. Håkedal, R. Tronstad, T. Vlasenko, I. Buchovskaja, S. Beringov, and M. Bauer: Presented at the 23rd European PV Solar Energy Conference, 1-5 September 2008, Valencia, Spain.

8. A.K. Søiland, J.O. Odden, B. Sandberg, K. Friestad, J.T. Håkedal, E. Enebakk, and S. Braathen: Presented in Silicon Materials Workshop, 7-8 October 2013, Rome, Italy.

9. M. Forster, P. Wagner, J. Degoulange, R. Einhaus, P. Wagner, J. Degoulange, R. Einhaus, G. Galbiatic, F.E. Roughieuxd, A. Cuevasd, and E. Fourmond: Sol. Energy Mater. Sol. Cells, 2014, vol. 120 , pp. $390-95$.

10. C. Modanese, M. Acciarri, S. Binetti, A.-K. Søiland, M.D. Sabatino, and L. Arnberg: Prog. Photovolt: Res. Appl., 2013, vol. 21, pp. 1469-77.

11. ASTM Standard Practice for Conversion Between Resistivity and Dopant Density for Boron-Doped, Phosphorus-Doped and Arsenic Doped Silicon, 1999.

12. M. Di Sabatino, A.L. Dons, J. Hinrichs, and L. Arnberg: Spectrochim. Acta B, 2011, vol. 66 (2), pp. 144-48.

13. C. Modanese, M. Di Sabatino, A.K. Soiland, and L. Arnberg: Phisica Status Solidi, 2011, vol. 8, pp. 713-16.

14. M.A. Green: Solar Cells, Operating Principles, Technology and System Applications, Prentice-Hall Inc, Kensington, 1998, pp. 96-98.

15. D. Macdonalda and A. Cuevas: J. Appl. Phys., 2011, vol. 109, pp. 043704 1-8.

16. Z.X. Liu, H. Takato, C. Togashi, and I. Sakata: Appl. Phys. Lett., 2010, vol. 96, pp. 153503-1-3.

17. S. Dannefaer, G. Suppes, and V. Avalos, J. Phys., 2009, vol. 21, pp. $0158021-6$.

18. J. Haunschild, J. Broisch, I.E. Reis, and S. Rein: Quality control of $\mathrm{Cz}$ grown silicon wafers in solar cell production using photoluminescence imaging. Present. 26th Eur. PV Solar Energy Conf. Exhib., 5-9 september 2011, Hamburg, Germany.

19. S. Rein and S. W. Glunz: J. App. Phys., 2005, vol. 98, issue 11 113711-1-12.

20. D. Macdonald, F. Rougieux, A. Cuevas, B. Lim, J. Schmidt, M. Di Sabatino, and L.J. Geerligs: J. App. Phys., 2009, vol. 105, pp. 093704-1-7.

21. www.eurostars-eureka.eu. Project E!6588 RESIM. 